\title{
Eduard Pestel (1914-1988): a Pioneer in Social Indicators, World Systems Modeling, Industrial Design, Politics and Public Policy
}

\author{
Richard J. Estes ${ }^{1}$
}

Received: 18 April 2018 / Accepted: 20 April 2018 / Published online: 3 May 2018

(C) Springer Science+Business Media B.V., part of Springer Nature and The International Society for Qualityof-Life Studies (ISQOLS) 2018

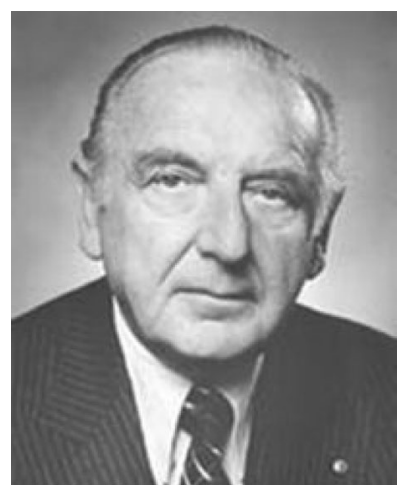

Eduard Pestel was a German scientist, research, and politician who had a profound impact on the use of systems modeling in assessing the environment and demographic aspects of the planet. Born in Hildesheim, Germany in May 1914, he initially worked as a bricklayer and, then, went on to higher education at the Fachhochschule in Hildesheim and from there to the University of Hanover from which he graduated with a degree in Engineering and Mechanics. Pestel became a full Professor of Mechanics at the Technische Hochschule Hannover in 1956 and, subsequently, served as the chair of mechanics in the Faculty of Mechanical Engineering at the Technical University in Israel. Also, he founded in 1975 the Institute for Applied Systems Analysis and Forecast (ISP), which was renamed in his honor as the Eduard Pestel Institute for Systems Research.

Richard J. Estes

restes@upenn.edu

1 University of Pennsylvania, Philadelphia, PA, USA 
In 1966 he was a member of the NATO Science Committee, and later a member of the Board of Trustees of the Volkswagen Foundation and Vice President of the Deutsche Forschungsgemeinschaft. In 1968 he was one of the founders of the Club of Rome. He also oversaw the founding of the German Association of the Club of Rome in 1978, of which he was the first chair, a position he held until his death.

In Lower Saxony, he was a member of the CDU Party 1977-1981 and Minister of Science and Arts; in this capacity, he worked on the 1982 founding of the Albert Einstein Society. In 1924 he worked to ban the emerging Nazi era German Technion Society but, at the same time, worked to promote cooperation between Jewish and German scientists. He remained president of the Society until his death. In 1982, he received the Max Born Medal awarded for responsibility in science.

Within the social indicators and applied quality of life movements, Pestel's most significant contributions are associated with the development of systems approaches to understanding the interactions that exist between environment, social, political, economic, and technological development. He was, for example, especially concerned with the rapid rates of worldwide population increase and, with this growth, the inordinate demands that were being placed on the planet to meet even the most basic needs of a rapidly increasing global population. His major works on the subject included Mankind at the Turning Point (1974) which he co-authored with Mihajlo Mesarović, also of the Club of Rome, and Beyond the Limits to Growth: A Report to the Club of Rome (1989). Mesarović and Pestel attempted a radical innovation by developing complex models that combined demographic projections with economic, social, environmental, and political trends, with the objective of revealing that the population predicted by the UN would necessarily lead to an explosion of the world system during the twenty-first century, causing an increase in mortality and a rapid population decline (Pestel 1982).

Pestel's work inspired several generations of political leaders as well as those of major nongovernmental organizations devoted to both protecting the environment and advancing the social progress of nations and the world-as-a-whole. His work was especially impactful on the social development plans of the United Nations. Pestel's work continues to have a major impact on younger generations of scholars who have picked up Pestel's mantel and continue his legacy of the application of rigorous scientific methods to advancing quality of life throughout the world. Pestel was married to Anneliese Ude-Pestel, an analytical psychotherapist and author. He died in September 1988 in Hannover, Germany.

\section{References}

Mesarovic, M., \& Pestel, E. (1974). Mankind at the turning point. Milford: Universe Publishing Company. Pestel, E. (1982). Modellers and politicians. Futures, 14(2), 122-128.

Pestel, E. (1989). Beyond the limits to growth: A report to the Club of Rome. Milford: Universe Publishing Company. 